\title{
Influence of Teacher Performance on Learning Achievement in Public Secondary Schools in Kisii County, Kenya
}

\author{
Gilbert Morara Nyakundi ${ }^{1,2, *}$ \\ ${ }^{1}$ Department of Educational Management and Curriculum Studies, School of Education, \\ Mount Kenya University, Kenya \\ ${ }^{2}$ Department of Educational Management, Policy and Curriculum Studies, School of \\ Education, Kenyatta University, Kenya \\ *Correspondence: Department of Educational Management and Curriculum Studies, School \\ of Education, Mount Kenya University, Kenya. Tel: 254-728-0003-0250. E-mail: \\ gnyakundi@mku.ac.ke
}

Received: March 2, 2018 Accepted: April 11, 2018 Published: May 13, 2018

doi:10.5296/ije.v10i2.12983 URL: https://doi.org/10.5296/ije.v10i2.12983

\begin{abstract}
Extant literature suggests that regular appraisal of teachers lead to progress in student learning achievement. However, the influence of teacher performance on achievement is not well documented hence the need for this study whose objectives were to (1) determine the relationship between teacher appraisal ratings and student learning achievement, (2) establish the relationship between student feedback ratings and learning achievement and (3) determine the influence of teacher performance on student learning achievement. Based on Locke's goal-setting and Vrooms' expectancy theories this study adopted explanatory sequential mixed methods design with population of 50,379 comprising 333 principals, 3,426 teachers and 46,620 students and a stratified sample of 397. Questionnaire reliability was .779 and .783 for teachers and students respectively. Quantitative research findings for the first and second objectives yielded Pearson's Correlation Coefficient $\mathbf{r}(27)=-.008, \mathrm{p}=.484$ (performance appraisal ratings) and $\mathrm{r}(27)=-.085, \mathrm{p}=.331$ (student feedback ratings) showing that appraisal ratings and student feedback ratings were not significantly related to learning achievement since p-values obtained were more than the critical alpha $(\boldsymbol{\alpha})$ set at .05 level of significance. For the third objective, the regression analysis model constructed to test the influence of teacher performance on learning achievement yielded Persons' $\mathrm{R}=.085$ indicating a weak positive relationship between the two variables. The $\mathrm{R}$-Squared $\left(\mathrm{R}^{2}\right)$ computed yielded a value of .007 , suggesting that teacher performance explained $.7 \%$ of student learning achievement. Qualitative findings confirmed that performance appraisal contributed minimally to student achievement due to weaknesses of the appraisal policy, low teacher
\end{abstract}


motivation, student characteristics, principal's characteristics and home background factors. It is thus recommended that Teachers Service Commission should consider expanding performance appraisal for teachers in secondary schools. In addition, all stakeholders should participate in capacity building programmes to strengthen the performance management process. Finally, further research to develop a performance management model for schools is essential.

Keywords: Appraisal ratings, student feedback ratings, teacher performance, learning achievement

\section{Introduction}

According to Edgar (2012) "understanding the learning process is a complex undertaking" but extant literature reveals numerous theoretical attempts to explain the process. Two major schools of thought are evident: Empiricism and rationalism (Schunk, 2004). Currently, "Education has moved to a more constructivist approach in which learning considers learner ability to construct new knowledge based on prior knowledge or experiences" (Kort, Reilly, \& Picard, 2001). The learning theories inform choice and development of instructional strategies. Globally, the role of students in teaching and learning is gradually expanding to include evaluation of the quality of teaching in classrooms. For instance, a study on "Measures of Effective Teaching" (MET) conducted by the Bill and Melinda Gates Foundation (2009-2013) involved students to evaluate teaching quality using tripod surveys. The MET study correlated student ratings with classroom observation ratings by trained professionals (Kane, Kerr \& Pianta, 2014). The results show that "tripod student ratings were more reliable than either value-added test score gains or classroom observations by trained professionals" (Ferguson, Phillips, Rowley, \& Friedlander, 2015).

Nationally, quality of learning is one of the four basic principles underlying Kenya's National Education Sector Plan (KNESP, 2013) for the period 2013-2018. The plan states that quality of learning is "about the setting of rigorous quality benchmarks in the curriculum and its delivery and assessment so as to ensure that the learning opportunities for all children and young people are maximized" (RoK, 2014. p.2). Notably, reform of the formal education system to reflect realities of the $21^{\text {st }}$ century and beyond is in process and as a result, there is deliberate focus on student learning and the outcomes of that process.

There are several bodies of research that focus on student learning achievement. Goe (2007) used the input, process and output framework to synthesize literature on the relationships between teacher quality and student learning achievement. Teacher inputs included qualifications and teacher characteristics such as attitudes, beliefs and self-efficacy. The process involved all class and out-of-class practices such as planning, classroom management, instructional delivery and interactions with students. Achievement was considered as teacher effectiveness which depended on student gains against predicted achievement (Goe, 2007). Research studies by Clotfelter, Ladd, and Vigdor (2006) and Harris and Sass (2007) found out that advanced degrees did not result in improvement of student learning achievement. However, content-oriented professional development had the greatest impact on student achievement 
(Harris \& Sass, 2007). Collaboration amongst teachers was found to influence student achievement (Leana \& Pil, 2006).

In Kenya, there is paucity of research on the influence of teacher performance on student learning achievement. Moreover, teachers seems to be challenged on the use of student achievement reports to progressively improve learning achievement. Kagete (2013) investigated "the extent to which test results are used by teachers in classrooms to enhance learning in secondary schools in Nairobi County. In a paper that was presented during the International Association for Educational Assessment" (IAEA) conference, in Tel-Aviv, Kagete "reports that teachers did not have adequate training on how to use assessment results and they assessed students for diagnostic purposes only using deficient assessment methods". Kagete "observed that reporting on student learning achievement in secondary schools is the prerogative of Kenya National Examinations Council" (KNEC) based on KCSE examination results which are minimally utilized to improve student learning.

Nyagosia, Waweru, and Njuguna (2013) conducted research to determine the relationship between school effectiveness and academic performance of students in secondary schools of Central Kenya. The findings show that there was significant relationship between performance of schools and instructional leadership, focus on school mission, school safety and orderliness, expectations for success, home-school relations, and opportunity to learn respectively. However, frequent monitoring of students' progress did not provide significant results.

Kimani, Njagi and Kara (2013) investigated the relationship between students' academic achievement and selected teachers demographic characteristics and classroom instructional practices respectively. The study found that teachers' age, gender, professional qualifications and teaching experience were not significantly related to academic achievement. Teachers' job group had significant and positive relationship with students' academic achievement in secondary schools. Teachers' weekly teaching workload, administration of students' classroom assignments, evaluation of students' Continuous Assessment Test (CATs) results, provision of individualized attention to weak students, time of completion of Form Four syllabus and setting performance targets for KCSE significantly affected students' academic achievement. Hence, this study was conducted to determine the influence of teacher performance and student learning achievement in public secondary schools in Kisii County.

Performance of teachers is an area that is pertinent to policymakers whose goal is to improve student learning achievement (AEE, 2008). Literature on teacher performance depicts four major areas of concern: Planning and preparation, management of classroom environments, instruction (Danielson, 2013; Tournaki, Lyublinskaya \& Carolan, 2009) and professional responsibilities (Danielson, 2013). Research studies show that whether teachers perform their teaching activities effectively or not depends on their qualifications, professional development, and experience. Goe, Bell, and Little (2008) described teachers who perform effectively as those who:

a) Have high expectations for all students and help students learn, as measured by value added or other test-based growth measures, or by alternative measures, 
b) Contribute to positive academic, attitudinal, and social outcomes for students such as regular attendance, on-time promotion to the next grade, on-time graduation, self-efficacy, and cooperative behaviour,

c) Use diverse resources to plan and structure on-going learning opportunities, monitor student progress formatively, adapting instruction as needed, and evaluate learning using multiple sources of evidence,

d) Contribute to the development of classrooms and schools that value diversity and civic-mindedness,

e) Collaborate with other teachers, administrators, parents and education professionals to ensure student success, particularly the success of students with special needs and those at high risk for failure (Goe et al, 2008. p.8).

Clotfelter et al (2007) and Darling-Hammond (2007) were of a similar view that teachers who perform effectively impact positively on student learning achievement. Similarly, Rockoff et al (2008) concluded that variations in student achievement were linked to differences in the performance of teachers. Furthermore, Gordon, Kane and Staiger (2006) posits that teacher performance in the classroom predicts student success than anything else, and that students will benefit exponentially if they are consistently taught by teachers who perform effectively

Research studies conducted in Tennessee (USA) attested that students given the most effective teachers for three years in a row made over twice the gains of comparable students assigned to the least effective teachers (Sanders \& Rivers 1996). Furthermore, research studies show that effective teachers significantly impact on a student's ability to learn by offsetting challenges such as low income levels and achievement gaps (Rivkin et al. 2002; Clotfelter et al. 2007). Teacher effects were responsible for $30 \%$ of variance in student learning achievement (Hattie, 2003). However, the research synthesis by Hattie (2003) focused on the behavioral characteristics of teachers and not the individual teacher attributes such as qualification, professional development, experience, and performance in teaching.

Teachers who do not perform are not expected to remain in classes especially in schools with good performance traditions. According to Gordon, Kane and Staiger (2006) ineffective teachers do not remain in classrooms in school systems deemed to be the best. Hanushek (2009) confirms that student learning achievement would increase significantly if 6 to 10 percent of least effective teachers were eliminated. However, Clotfelter, Ladd and Vigdor (2007) and Harris and Sass (2007) established that performance of teachers improve over the first five years on the job and that the benefits of experience on performance are less clear after that point.

\section{Statement of the Problem}

The Kenyan formal education system is undergoing reforms to reflect realities of the $21^{\text {st }}$ century and beyond. As a result, a new performance appraisal policy for teachers was introduced in 2016 with the aim of improving teacher effectiveness and student learning 
achievement. Appraisals for teachers provide feedback on their performance and identify areas where they require development and support. However, there is paucity of research on the influence of teacher performance on student learning achievement particularly in public secondary schools. As a result, the dependability of learning achievement on performance appraisal for teachers is unclear especially in Kisii County which recorded low student learning achievement in the Kenya Certificate of Secondary Education (KCSE) examinations for the last decade, hence necessitating this study.

\section{Objectives of the Study}

The objectives of this study were to:

a) determine the relationship between teacher appraisal ratings and student learning achievement in public secondary schools in Kisii County

b) establish the relationship between student feedback ratings and student learning achievement.

c) determine influence of teacher performance on student learning achievement in public secondary schools in Kisii County

\section{Research Hypotheses}

This study sought to test the following three null hypotheses:

1. $\mathrm{H}_{0}$ : Teacher appraisal ratings are not significantly related to student learning achievement in public secondary schools in Kisii County at $\alpha=.05$ confidence level.

$\mathrm{H}_{1}$ : Appraisal ratings for teachers are significantly related with student learning achievement in public secondary schools in Kisii County at $\alpha=.05$ confidence level.

2. $\mathrm{H}_{0}$ : Student feedback ratings are not significantly related with student learning achievement at $\alpha=.05$ confidence level.

$\mathrm{H}_{1}$ : Student feedback ratings are significantly related with student learning achievement at $\alpha=.05$ confidence level.

3. $\mathrm{H}_{0}$ : Teacher performance does not significantly influence student learning achievement at $\alpha=.05$ confidence level.

$\mathrm{H}_{1}$ : Teacher performance significantly influence student learning achievement at $\alpha=.05$ confidence level. 


\section{Research Design and Methodology}

This study adopted explanatory sequential mixed methods design. The population was 50,379 comprising of 3,426 teachers and 46,620 students. Statistical sampling technique was used to determine a sample of 397 by Slovene's formula. In the first quantitative phase, the performance of each principal and teacher who participated in the study was evaluated. Data was obtained using two questionnaires one for principals and teachers and the other for students. Both instruments were pre-tested leading to some items being dropped and or adjusted in order to boost their validity after piloting. Using the Cronbach Alpha method, instrument reliabilities were ascertained at .779 and .783 for seven items in each of the two instruments respectively. Data obtained in phase one was analyzed using both descriptive and inferential statistics notably percentages, Pearson's Correlation Coefficient Alpha, Chi-square and regression analysis.

In the second qualitative phase, interviews were conducted for 11 teachers (inclusive of 3 principals) in which data was obtained using interview schedules. The qualitative phase of this study was necessary for purposes of completeness of information obtained in phase one. It also reduced the weaknesses of solely depending on findings from the first phase that were based on a complex issue such as the influence of teacher performance on student learning achievement. Furthermore, qualitative findings confirmed the trustworthiness of inferences gained from quantitative findings obtained in phase one.

\section{Research Findings}

The first objective of this study was to find out the relationship between appraisal ratings and student learning achievement. Pearson's Correlation Coefficient method yielded $\boldsymbol{r}(27)=-.008$, $\mathrm{p}=.484$ for performance appraisal ratings showing that it was not significantly related to learning achievement since $\mathrm{p}$-value obtained was more than the critical alpha $(\boldsymbol{\alpha})$ set at .05 level of significance. Chi square test results were: $\chi^{2}(\mathrm{df}=12, \mathrm{~N}=27)=13.275, \mathrm{p}=.349$ showing that performance appraisal ratings was not significantly associated with student learning achievement given that the $p$-value obtained was more than the critical alpha set at .05 level of significance. This finding led to the retention of the first hypothesis that appraisal ratings are not significantly related to student learning achievement in public secondary schools in Kisii County.

The second objective of this study was to establish the relationship between student feedback ratings and student learning achievement. Pearson's Correlation Coefficient method yielded $\mathrm{r}(27)=-.085, \mathrm{p}=.331$ showing that student feedback ratings were not significantly related with student learning achievement since the p-value obtained was more than the critical alpha set at .05 level of significance. Chi square test results yielded $\chi^{2}(\mathrm{df}=8, \mathrm{~N}=27)=6.715$, $\mathrm{p}=.568$ showing that student feedback ratings were not significantly associated with student learning achievement since the $p$-value obtained was greater than the critical alpha set at 05 level of confidence. This finding led to the adoption of the second hypothesis that student feedback ratings are not significantly related to student learning achievement in public 
secondary schools in Kisii County.

The third objective of this study was to determine the influence of teacher performance on student learning achievement. Results of the regression model constructed for this purpose yielded Persons' $\mathrm{R}=.085$ which indicate a weak positive relationship between teacher performance and student learning achievement. The R-Squared $\left(\mathrm{R}^{2}\right)$ computed yielded a value of .007 , suggesting that teacher performance explained $.7 \%$ of student learning achievement. The adjusted $\mathrm{R}^{2}$ also confirmed that teacher performance explained over $.6 \%$ of the variation in student learning achievement in public secondary schools in Kisii County. Furthermore, the $p$-value computed by the Statistical Package for the Social Sciences (SPSS) was .910 which is more than the statistical significance level $\boldsymbol{\alpha}=.05$.

Additionally, the standard error of estimate (E) was found to be .799 , suggesting that there were other factors of the magnitude of .799 that influence student learning achievement that were not observed or taken into consideration during the first quantitative phase of the study hence the need for the second qualitative phase. An analysis of beta weight $\boldsymbol{\beta}$ for the two variants of teacher performance shows that the contribution of appraisal ratings to student learning achievement $\boldsymbol{\beta}_{\mathbf{1}}=.009$, controlling for student feedback on teacher performance. This result, shows that one unit change in appraisal ratings is expected to cause .009 change in student learning achievement. Likewise, the contributions of student feedback on teacher performance was $\boldsymbol{\beta}_{2}=-.086$ showing that one unit change in student feedback is expected to cause -.086 change in student learning achievement. This finding led to the third hypothesis being retained that teacher performance does not significantly influence student learning achievement in public secondary schools in Kisii County.

\section{Discussions, Conclusions and Recommendations}

This study led to the following discussions, conclusions and recommendations:

\subsection{Discussions}

The first objective of this study was to establish the relationship between appraisal ratings and student learning achievement. Findings of both quantitative and qualitative phases of this study were in affirmative that appraisal ratings were not significantly related with student learning achievement. Similar results were obtained for student feedback ratings in respect to the second objective. The findings of the third objective shows that teacher performance did not significantly influence student learning achievement in public secondary schools in Kisii County.

The findings of this study contradict previous research studies which established that teacher performance significantly contributed to student learning achievement (Clotfelter et al, 2007; Darling-Hammond, 2007; Gordon, Kane \& Staiger, 2006; Kane, Kerr \& Pianta, 2014; Rivkin et al, 2002; Rockoff et al, 2008; and, Sanders \& Rivers, 1996). However, findings from these studies were of the view that the contribution of teacher performance to student learning achievement tended to decline beyond the first five years in teaching. 
Literature informs us further that student ratings provides an excellent source of evidence for both formative and summative decisions, and consequently recommends use of multiple sources (Arreola, 2000 in Berk, 2005). The findings of this study underscores the fact that intervening variables between teacher performance and learning achievement are pertinent. Issues such as the performance appraisal policy, student characteristics, teacher motivation, and principal characteristics collectively influence student learning achievement in a substantial way and a teacher performance appraisal framework should consider them.

\subsection{Conclusions}

Conclusions are based on the findings that teacher performance was not significantly related or associated with student learning achievement. As a result, the null hypothesis that teacher performance does not significantly influence student learning achievement in public secondary schools in Kisii County was adopted. These findings were attributed to weaknesses of the performance appraisal policy namely unclear performance appraisal standards, unknown validity and reliability of performance measurement tools and ignorance of appraisers and appraisees on the performance appraisal process. Furthermore, issues of teacher motivation, principal's and student characteristics also emerged as contributing factors. These findings led to the conclusion that teacher performance had minimal contribution to student learning achievement in public secondary schools in Kisii County.

\subsection{Recommendations}

The findings of this study leads to the following recommendations:

a) The Teachers Service Commission, TSC, should consider broadening the performance appraisal framework for teachers in public secondary schools.

b) Stakeholders in public secondary schools should complete in-depth capacity building programmes to strengthen the performance management process.

c) Further research is recommended to develop a performance management model for schools.

\section{References}

Alder, N. (2002). Interpretations of the meaning of care: Creating caring relationships in urban middle school classrooms. Urban Education, 37(2), 241-266. https://doi.org/10.1177/0042085902372005

Allen, J. P., Gregory, A., Mikami, A. Y., Lun, J., Hamre, B., \& Pianta, R. C. (2013). Observations of effective teacher-student interactions in secondary school classrooms: Predicting student achievement with the Classroom Assessment Scoring System Secondary. School Psychology Review, 42(1), 76-98.

Allen, J.P., Pianta, R. C., Gregory, A., Mikami, A. Y., \& Lun, J. (2011). An interaction based approach to enhancing secondary school instruction and student achievement. Science, 
333(6045), 1034-1037. http://dx.doi.org/10.1126/science.1207998

Applebee, A. N., Langer, J. A., Nystrand, M., \& Gamoran, A. (2003). Discussion-based approaches to developing understanding: Classroom instruction and student performance in middle and high school English. American Educational Research Journal, 40(3), 685-730. https://doi.org/10.3102/00028312040003685

Bransford, JD., Brown, AL., \& Cocking, R. (1999). How People Learn: Brain, Mind, Experience, and School. Committee on Developments in the Science of Learning. National Research Council, National Academy Press, Washington DC. https://doi.org/10.17226/9853

Broad, K., \& Evans, M. (2006) A review of Literature on professional development content and delivery modes for experienced teachers. University of Toronto, Canada. https://www.oise.utoronto.ca/ite/UserFiles/File/AReviewofLiteratureonPD.pdf

Butler, A. C., Godbole, N., \& Marsh, E. J. (2013). Explanation feedback is better than correct answer feedback for promoting transfer of learning. Journal of Educational Psychology, 105(2), 290-298. http://dx.doi.org/10.1037/a0031026

Clotfelter, C.T., Ladd, H.F., \& Vigdor, J.L. (2006). How and why do teacher credentials matter for student achievement? National Bureau of Economic Research, Working Paper 2828. Cambridge, MA: National Bureau of Economic Research https://caldercenter.org/sites/default/files/1001058_Teacher_Credentials.pdf

Cooper, K. S. (2013). Eliciting engagement in the high school classroom: A mixed methods examination of teaching practices. American Educational Research Journal, 51(2), 363-402. http://dx.doi.org/10.3102/0002831213507973

Cothran, D. J., Kulinna, P. H., \& Garrahy, D. A. (2003). "This is kind of giving a secret away..." Students' perspectives on effective class management. Teaching and Teacher Education, 19(4), 435-444. http://dx.doi.org/10.1016/S0742-051X (03)00027-1

Crumpton, H. E., \& Gregory, A. (2011). "I'm not learning”: The role of academic relevancy for low-achieving students. The Journal of Educational Research, 104(1), 42-53. https://doi.org/10.1080/00220670903567398

Culbertson, D. M. (2012). Effective mathematics instructional strategies for middle school students (Doctoral Dissertation, Walden University). Retrieved from https://www.andrews.edu/sed/leadership_dept/webinars/presentationdocuments/the_eff ctive_mathematics_classrroom.pdf

Darling-Hammond, L., \& Youngs, P. (2007). Defining highly qualified teachers: What does scientifically-based research tell us? Educational Researcher, 31(9), 1325 https://doi.org/10.3102/0013189X031009013

Edgar, D.W. (2012). Learning theories and historical events affecting instructional design in education: Recitation literacy toward extraction literacy practices. Retrieved on August 30, 2016 from http://sgo.sagepub.com. https://doi.org/10.1177/2158244012462707.20122 
Ferguson, R.F., Phillips, S.F., Rowley, J.F.S., \& Friedlander, J.W. (2015). The influence of teaching beyond standardized test scores: Engagement, mindsets, and agency. Raikes Foundation. 10/08/2016 Retrieved from http://www.agi.harvard.edu/projects/TeachingandAgency.pdf

Ferreira, M. M., \& Bosworth, K. (2001). Defining caring teachers: Adolescents' perspectives. Journal of Classroom Interaction, 36(1), 24-31.

Goe, L. (2007). The link between teacher quality and student outcomes: A research synthesis. Washington, DC: National Comprehensive Center for Teacher Quality/ Retrieved from http://www.tqsquare.org/link.php

Gordon, R., Kane, T.J., \& Staiger, D.O. (2006). Identifying effective teachers using performance on the job. Washington, DC: The Brookings Institution. https://www.brookings.edu/wp-content/uploads/2016/06/200604hamilton_1.pdf

Hamre, B. K., \& Pianta, R. C. (2005). Can instructional and emotional support in the first grade classroom make a difference for children at risk of school failure? Child development, 76(5), 949-967. https://doi.org/10.1111/j.1467-8624.2005.00889.x

Harris, D. N., \& Sass, T.R. (2007). Teacher training, teacher quality and student achievement. Center for Analysis of Longitudinal Data in Educational Research. https://files.eric.ed.gov/fulltext/ED509656.pdf

Hulleman, C. S., Godes, O., Hendricks, B. L., \& Harackiewicz, J. M. (2010). Enhancing interest and performance with a utility value intervention. Journal of Educational Psychology, 102(4), 880-895. http://dx.doi.org/10.1037/a0019506

Kagete, P. (2013). Classroom 'assessment -for-learning' in secondary schools in Kenya. A paper presented at the $39^{\text {th }}$ Annual Conference of the International Association for Educational Assessment (IAEA). Tel $\quad$-Aviv, Israel. http://www.iaea.info/papers.aspx?id=81

Kane, T.J., Kerr, K.A., \& Pianta, R.C. (2014). Designing teacher evaluations systems: new guidance from the Measures of Effective Teaching Project. San Francisco, Jossey-http://janbri.nl/wp-content/uploads/2015/01/Designing-Teacher-Evaluation-Syste ms_freePDF.pdf

Kimani, N. G., Kara, M.A., \& Njagi, W.L. (2013). Teacher factors influencing students' academic achievement in secondary schools in Nyandarua County, Kenya. International Journal of Education and Research, 1(3), 114. Maputo. ADEA.

Leana, C.R., \& Pil, F.K. (2006). Social capital and organizational performance: Evidence from urban public schools. Organization Science, 17(3), 353-366 https://doi.org/10.1287/orsc.1060.0191

Matsumura, L. C., Slater, S. C., \& Crosson, A. (2008). Classroom climate, rigorous instruction and curriculum, and students' interactions in urban middle schools. The Elementary School Journal, 108(4), 293-312. 
McElhone, D. (2012). Tell us more: Reading comprehension, engagement, and conceptual press discourse. Reading Psychology, 33(6), 525-561.

Nyagosia, P.O., Waweru, N.S., Njuguna, W.. Njuguna (2013). Factors influencing academic achievement in public secondary schools in central Kenya: An effective schools perspective. Educational Research International, 2(2).

Rice, J. K. (2003). Teacher quality: Understanding the effectiveness of teacher attributes. Washington, DC: Economic Policy Institute. https://www.epi.org/publication/books_teacher_quality_execsum_intro/

Rodger, S., Murray, H. G., \& Cummings, A. L. (2007). Effects of teacher clarity and student anxiety on student outcomes. Teaching in Higher Education, 12(1), 91104.

Rubie-Davies, C. M. (2007). Classroom interactions: Exploring the practices of high and low expectation teachers. British Journal of Educational Psychology, 77(2), 289306. https://doi.org/10.1348/000709906X101601

Schacter, J., \& Thum, Y. M. (2004). Paying for high-and low-quality teaching. Economics of Education Review, 23(4), 411-430. Doi: 10.1016/j.econendurev.2003.08.002

Schunk, D. H. (2004). Learning theories: An educational perspective. Upper Saddle River, NJ: Pearson. ISBN 01303849689780130384966

Wilson, B. L., \& Corbett, D. (2001). Listening to urban kids: School reform and the teachers they want. Albany, NY: SUNY Press.

\section{Copyright Disclaimer}

Copyright for this article is retained by the author(s), with first publication rights granted to the journal.

This is an open-access article distributed under the terms and conditions of the Creative Commons Attribution license (http://creativecommons.org/licenses/by/3.0/). 